\title{
Ezra Pound's Version of Shijing Translation
}

\author{
Hao Zhang \\ North China Electric Power University \\ Baoding, China
}

\begin{abstract}
It is a vexed question in translatology field that whether poetry is translatable. People said that translating is pronouncing sentence of death on understanding and some wiseacre has said that translating is just like the back of a Turkey tapestry. This thesis applies the principles of correspondence to the study of Shijing translation by Pound's versions of Shijing from the aspects of formal equivalence and dynamic equivalence to prove the possibility of poetry translation and provide theoretical guidance function to poetry translation.
\end{abstract}

Keywords—principles of correspondence; Shijing translation; Ruist; Imagism

\section{TRANSLATOR'S PURPOSES AND STRATEGIES}

The purposes of Pound translating Shijing are to translate the old for the present and express himself by translating Confucianism which determined his focus of attention directed toward the receptor response but not so much toward the source message. Viewing from Pound's translating purposes, his translation of Shijing produced a dynamic rather than a formal equivalence.

The greatest cultural influence over Pound came perhaps from ancient China. Early in 1908, when Pound lived in London, he discovered the wisdom of ancient Chinese philosophers in Allen Upward's version of Lun $\mathrm{Yu}$ and Lcrcmmer-Byng's version of The Sayings Kung the Master. Meanwhile, He saw no effective cure in Christianity for the diseases of his times. Thus he looked about and turned to the East, he found Messiah in Confucius and the medicine for the disease of the West. Pound said that Confucius is much wiser than ST. Paolo. Pound published articles in New Times and thought highly of Confucianism which reflected social problems profoundly and respects personal value and personality. Afterwards, while producing Cathay and Cantos and translating Great Learning, Confucian Analects, Doctrine of the Mean and Shijing, Pound's original intention of enlightening and civilizing the barbarous Occident through Confucius ideology had never changed. In the 1930s, Pound further discovered that the Chinese Classics Shijing is the Political manual for ancient Chinese emperors. He said that Chinese emperor in Qing Dynasty had ordered to render Shijing into manju because of its political instrument value. Whereupon, Pound decided by means of rendering Shijing into English to further preach Confucian morality in the West. Italy's political situation during the Second World War made Pound realize that Confucian canons including Shijing translations kind of became politics demands which were used to State Confucian ethics and political views. He believed that what he could do for Italy is to translate some Confucian canons every year and deposit them into people's minds. Pound expected that could affect the contemporary readers, just like his Cathay did, and the effects should be the same as that the original message affected Chinese readers. He states explicitly that the case for translations making sense by declaring for "more sense and less syntax". The so called "more sense" refers to the translator could experience and communicate the sense of the original message, especially the modern mind in the source text. That because semantic translation would make the source text be deprived of vitality and some contacts with certain historical conditions. So, translation should be interpretative and the translator may write a new poem in the process of translation. Or, more precisely, translation should be experimental with the aim of getting in touch with the real life no less than the original text got in touch with the contemporary world. From here we see that the intendment of Pound translating Shijing is to translate the old for the preset and express himself by translating Confucianism.

\section{IMAGISM IN SHIJING TRANSLATION}

The conformance of a translation to the receptor language and culture as a whole is an essential ingredient in any stylistically acceptable translation. Such an adjustment to the receptor language and culture must result in a translation that bears no obvious trace of foreign origin. (Nida, 2004:158) In fact, Pound carries out imagism in his translation works. He stated that do not try to present the integral meaning of a piece of work but to translate the exact work, cluster of fused ideas or even broken image. And the exact work, according to Richard Aldington, another of the first Imagists, must bring the effect of the object before the reader as it had presented itself to the poet's mind at the time of writing. An imagist poem enables the reader to see the physical thing rather than put him through an abstract process. This resulted that in Pound's version of Shijing the focus of attention is directed, not so much toward the source message, as toward the receptor response. This determined the dynamic equivalence orientation of Ezra Pound's version of Shijing.

Something like an Imagist manifesto came out in 1912 in which Pound and Flint laid down three Imagist poetic principles:

- Direct treatment of the "thing," whether subjective or objective; 
- To use absolutely no word that does not contribute to the presentation;

- As regarding rhythm, to compose in the sequence of the musical phrase, not in the sequence of a metronome.

The first principle, with its emphasis on direct treatment, indicates a desire to make the expression resemble the "object" as closely as art can make it. By "direct," Pound means no fuss, frill, or ornament. The second stresses economy of expression, a reaction to the nineteenth-century tendency of philosophical "padding" of extra-poetic matter, or "emotional slither." To Ezra Pound any unnecessary word represents a loss of precision and a moral and artistic defection. The third concerns a breaking away from conventional prosody and the use of free verse, and the interrelationship between music and verse. Pound did not mean to sponsor "free verse" as the only verse form to use: he advocated freedom in verse. "Free Verse" means form, not formlessness.

Pound's version of Shijing followed his three imagist poetic principles. Pound's version of Shijing conducted total imagism strategy all the way round. What is remarkable is that, in the most cases, these images refer to the same objects with different morals comparing with the images in the source text. Therefore, the images in his translation are kind of original invention based on the source poems. Give some examples as follows.

\section{No FuSs, FriLL, OR ORNAMENT LANGUAGE}

Ezra Pound states the case for translations making sense by declaring for "more sense and less syntax."

In addition to making sense, translations must also convey the "spirit and manner" of the original. A natural translation involves two principal areas of adaptation, namely, grammar and lexicon. In general the grammatical modifications can be made the more readily, since many grammatical changes are dictated by the obligatory structures of the receptor language. That is to say, one is obliged to make such adjustments as shifting word order, using verbs in place of nouns, and substituting nouns for pronouns. The lexical structure of the source message is less readily adjusted to the semantic requirements of the receptor language, for instead of obvious rules to be followed, there are numerous alternative possibilities. (Nida, 2004:156)

Chinese poetry always seeks conceived conception magnificently that asks for the poet richly responded with the images. This form of ideology representing in language appears to be juxtaposed images without any intellectual participation and logistic analysis. This form of ideology is somewhat similar to the montage. Under such ideology, the poet melted himself and became a partial of the image, so that he forgot analyzing or too comprehend to express. Therefore the interpreting duty for the relationship and significance between images was all left to the reader. Pound imitated the characteristics of Chinese language and adopted the montage skill in the process of Shijing translation. Sure Pound's chief end of adopting this skill is not to pursue the language style loyalty of the translated text but to reinforce the translated poem's artistic effect. This coincides with Imagist poetic principles.

\section{FREE VERSE}

A translation which aims at dynamic equivalence inevitably involves a number of formal adjustments, for one cannot have his formal cake and eat it dynamically too. Something must give! The translating of poetry obviously involves more adjustments in literary form than does prose, for rhythmic forms differ far more radically in form, and hence in esthetic appeal. As a result, certain rhythmic patterns must often be substituted for others. (Nida, 2004:159)

Conventional English poems generally consist of three to six foots in every line and the poetical meter usually is tidy. Comparing with conventional English poems, Pound's version of Shijing adopted a kind of new form. Judging from the examples mentioned above, the outstanding feature was shown in the aspect of the lines of various lengths. It is the extremely short line that made the rhythm lively and quick and the conventional strict metrical is hardly to find in his version

\section{CONCLUSION}

Pound is not a Sinologist. He didn't know Chinese language and culture well and he had specific translation strategy in the course of translation. Pound's version of Shijing is impossible to cling to cultural connotation of original works. But Pound is a great poet and he had his own special learning mode for Shijing. So his translation had creation of poetic necessarily. Pound's version of Shijing as translation literature is undoubtedly a successful one. The status and influence in English and American literature had proved it strongly. Pound's successful is owing to two points. Firstly, he took great pains to perform practical method of translating the old for the present. Because of the principle, Pound's translation got rid of subordinate relationship of translated works and attained independent art of life. Secondly he followed imagism principle. Because of the principle, Pound's translated works could get into English literature successfully and became a component of imagism poetics. Under the instruction of the two principles, Pound cast off operation of language level in essence and took great pains to gain understanding and to surmount in spirit and got into creation state. Clinging to the source text seemed not to be his principle and target. The original work was not impassably criterion but just was the source of his wisdom. Thus he could keep gesture of master in the course of translation, express heartily in realm of poem and play his own poetics and imagination heartily. Practical principle made Pound's translation had realistic social and political meaning. Imagism principle made Pound's translation had art charm of Imagism poem and important meaning for further develop and perfect Imagism poetics. Maybe it is the dynamic integration of the two parts that makes Pound's version of Shijing has life. If we understand the two principles, we can understand Pound's Shijing translation. 


\section{ACKNOWLEDGEMENT}

The research was supported by "the Fundamental Research Funds for the Central Universities of China" (Grant No.13MS124).

\section{REFERENCES}

[1] Nida, E.A.Toward a Science of Translating. [M]. Shanghai Foreign Language Education Press, 2004.

[2] James Legge. The Book of Poetry: Chinese Text with English Translation. [M]. Shanghai: The Commercial Press, LTD, 1936.

[3] Pound, Ezra. Poems and Translation.[M].Library of America, 2003. 